\title{
OPTIMALISASI PENGGUNAAN MODEL BENGKEL SASTRA UNTUK MENINGKATKAN KEMAMPUAN MAHASISWA PGSD MENULIS DAN MEMUSIKALISASI PUISI
}

\author{
Etty Rohayati ${ }^{1}$ \\ Kurniawati ${ }^{2}$
}

\begin{abstract}
Abstrak
Penelitian ini dilandasi oleh masalah utama yakni rendahnya kemampuan mahasiswa PGSD dalam berekspresi sastra baik ekspresi tulis maupun ekspresi performa. Tujuan penelitian ini adalah untuk menjelaskan perbedaan kemampuan menulis puisi antara mahasiswa PGSD UPI Kampus Cibiru yang mendapatkan pembelajaran dengan menggunakan model bengkel sastra dan yang tidak menggunakan model bengkel sastra; perbedaan kemampuan musikalisasi puisi antara mahasiswa PGSD UPI Kampus Cibiru yang mendapatkan pembelajaran dengan menggunakan model bengkel sastra dan yang tidak menggunakan model bengkel sastra; dan faktor yang paling dominan berperan dalam mengembangkan kemampuan mahasiswa PGSD UPI Kampus Cibiru menulis dan memusikalisasi puisi. Hasil penelitian ini menunjukkan bahwa (1) terdapat perbedaan yang signifikan antara kemampuan menulis puisi mahasiswa kelas eksperimen yang mendapatkan pembelajaran dengan model bengkel sastra dan kelas kontrol yang tidak mendapatkan pembelajaran dengan model bengkel sastra; (2) terdapat perbedaan yang signifikan antara kemampuan memusikalisasi puisi mahasiswa kelas eksperimen yang mendapatkan pembelajaran dengan model bengkel sastra dan kelas kontrol yang tidak mendapatkan pembelajaran dengan model bengkel sastra; dan (3) faktor utama yang memengaruhi kemampuan mahasiswa menulis puisi dapat dikategorikan menjadi 3 kategori utama dan faktor utama yang memengaruhi kemampuan mahasiswa memusikalisasi puisi dapat dikategorikan menjadi 3 kategori utama.
\end{abstract}

Kata Kunci : Model Bengkel Sastra, Menulis Puisi, Memusikalisasi Puisi

\section{A. Latar Belakang Penelitian}

Proses pembelajaran di perguruan tinggi yang merupakan inti dari proses pendidikan tinggi, harus dilakukan dengan menitik beratkan pada pengembangan potensi yang dimiliki mahasiswa sehingga mahasiswa memperoleh bekal guna menghadapi kehidupan di masyarakat dan dunia kerja. Proses pembelajaran bukan proses memaksakan kehendak, tetapi merupakan suatu upaya menciptakan kondisi yang kondusif bagi perkembangan mahasiswa, yaitu memberikan kemudahan bagi mahasiswa untuk mengembangkan dirinya. Konsep ini berlaku pula dalam proses perkuliahan bahasa dan sastra di perguruan tinggi.

Namun demikian, perkuliahan yang dilakukan di perguruan tinggi nyatanya masih jauh dari harapan tersebut. Kondisi pengajaran bahasa dan sastra di PGSD

\footnotetext{
${ }^{1}$ Dosen UPI Kampus Cibiru

${ }^{2}$ Dosen UPI Kampus Cibiru
} 
UPI Cibiru pun pada kenyataannya sering dilakukan dosen hanya mengharuskan mahasiswa melahap semua buku teks untuk menemukan kaidah-kaidah dan teoriteori yang telah ada ini tentu saja jauh dari harapan yang mengharuskan dosen menjadi mitra diskusi mahasiswa dalam memahami, menghayati, dan menulis berbagai karya. Dengan kata lain, dosen yang memberi kuliah dengan berbekal buku-buku wajib semata-mata tidak dapat membawakan peranannya dengan baik guna memberikan berbagai pengalaman kepada mahasiswa calon guru bahasa dan sastra SD tentang apresiasi bahasa dan sastra dan menulis berbagai karya.

Usaha perombakan pengajaran bahasa dan sastra di perguruan tinggi selain ditekankan pada pelaksanaan berbagai kegiatan kebahasaan dan kesastraan juga harus ditekankan pada perubahan penggunaan model perkuliahan bahasa dan sastra yang selama ini masih dipandang monoton. Salah satu model pengajaran yang dapat memberikan pengetahuan dan pengalaman bahasa dan sastra yang kreatif bagi mahasiswa adalah model bengkel sastra. Melalui bengkel sastra ini bukan hanya mahasiswa yang dituntut aktif berolah kreatif, dosen pun dituntut terlibat langsung dalam proses berolah kreatif.

Guna memecahkan masalah tersebut salah satu alternatif yang dapat dipilih adalah dengan diterapkannya model pembelajaran kreatif berupa model bengkel sastra. Melalui kerja bengkel sastra, mahasiswa PGSD UPI Cibiru akan dibina kemampuan apresiasi sastranya sekaligus dibina tentang berbagai model mengajarkan bahasa dan sastra di sekolah dasar. Pada bengkel sastra, minat, motivasi, dan potensi mahasiswa akan digali terkait dengan kariernya di berbagai tenaga profesional di sekolah dasar dan pekerja bahasa di dunia kepenulisan. Dengan demikian, bengkel sastra diperlukan untuk mereduksi kesalahan konsep dan penguasaan profesional yang verbalistis sehingga diperoleh kompetensi profesional yang sesuai dengan standar kompetensi baik sebagai guru maupun sebagai pekerja di bidang penulisan. Sejalan dengan uraian ini, hasil penelitian ini diharapkan berkontribusi bagi pemecahan masalah pendidikan yaitu untuk meningkatkan kualitas pendidikan dan meningkatkan relevansi hasil pendidikan sesuai dengan tuntutan market signal dan stakeholders. Secara khusus kontribusi ini adalah (1) menyumbangkan optimalisasi penerapan model pembelajaran bengkel sastra dan (2) meningkatkan kemampuan musikalisasi puisi para mahasiswa.

Berdasarkan latar belakang di atas dapat dikemukakan masih banyak masalah yang ditemukan dalam pola pembelajaran sastra di lapangan. Beberapa masalah tersebut tidak mungkin dipecahkan sekaligus. Oleh karenanya, masalah dalam penelitian ini akan dibatasi. Masalah yang akan dicari pemecahannya melalui penelitian adalah (1) pola pembelajaran sastra di perguruan tinggi yakni di Program Studi PGSD UPI Kampus Cibiru masih bersifat verbalistis terjadi; (2) ruang lingkup pembelajaran sastra yang akan dipecahkan dibatasi pada masalah pembelajaran ekspresi sastra; dan (3) ruang lingkup kajian yang akan dikaji adalah peningkatan kemampuan mahasiswa menulis dan memusikalisasi puisi.

Sejalan dengan permasalahan di atas penelitian ini bertujuan untuk tujuan untuk menjelaskan (1) perbedaan kemampuan menulis puisi antara mahasiswa PGSD UPI Kampus Cibiru yang mendapatkan pembelajaran dengan menggunakan model bengkel sastra dan yang tidak menggunakan model bengkel sastra; (2) 
perbedaan kemampuan musikalisasi puisi antara mahasiswa PGSD UPI Kampus Cibiru yang mendapatkan pembelajaran dengan menggunakan model bengkel sastra dan yang tidak menggunakan model bengkel sastra; dan (3) faktor yang paling dominan berperan dalam mengembangkan kemampuan mahasiswa PGSD UPI Kampus Cibiru menulis dan memusikalisasi puisi.

\section{B. Tinjauan Teoretis}

\section{Model Bengkel Sastra}

Model bengkel sastra adalah model mengajar yang menekankan pada kegiatan olah aktivitas kreatif dengan melakukan kegiatan bongkar pasang dan proses tambal sulam sampai karya yang dihasilkan agar benar-benar optimal. Melalui model ini penciptaan dan penampilan karya akan semakin mantap dan estetis. Model bengkel sastra ini berorientasi pada teori William J.J. Gordon yaitu Synectic Teaching Models yang menurut pengelompokan Joyce et al. (2000: 19) termasuk ke dalam keluarga atau kelompok The Information Processing Family of Models.

Model sastra memiliki enam fase yaitu (1) penemuan masalah(2) respons karya (3) sharing pendapat tentang karya (4) kontak argumen tentang karya (5) eksperimen karya (6) menulis kembali karya. Untuk lebih jelasnya sintaksis model ini dapat dilihat pada diagram di bawah ini.

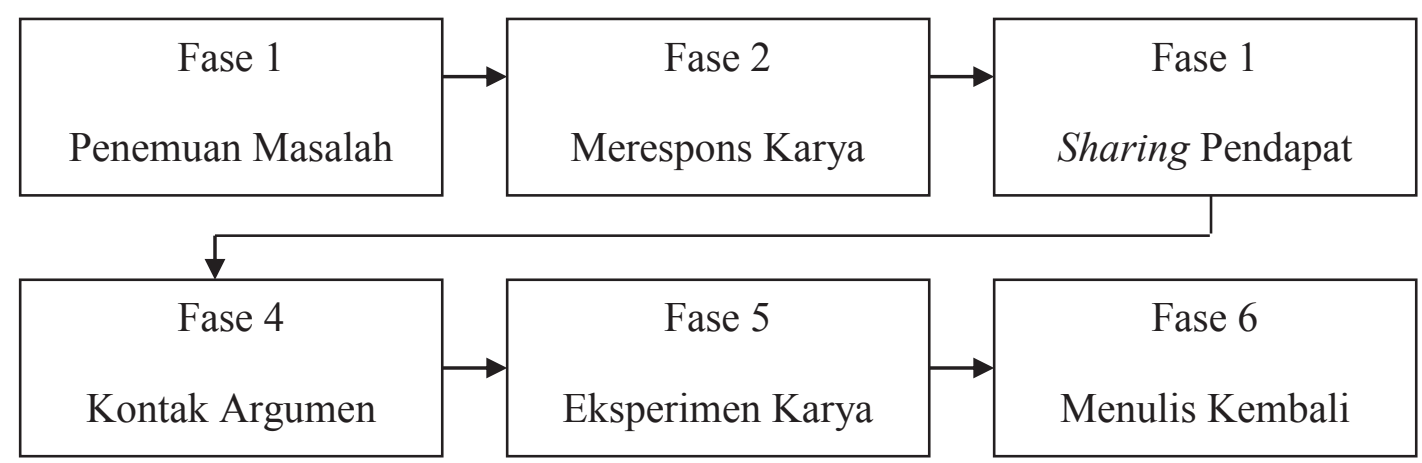

Gambar 1

Sintak Model Bengkel Sastra (Abidin, 2005: 18)

Sejalan dengan bagan di atas, model mengajar bengkel sastra menempuh strategi sebagai berikut.

a. Fase kesatu: mahasiswa menerima informasi tentang prosedur bengkel. Setelah itu, mahasiswa dihadapkan karya yang problematik untuk menemukan masalah-masalah dalam karya tersebut. Karya yang problematik tersebut bisa berupa karya hasil karya mahasiswa sebelumnya.

b. Fase kedua: mahasiswa memberikan respons dan tanggapan terhadap karya yang telah dibacanya tersebut.

c. Fase ketiga: mahasiswa melakukan kegiatan bertukar pikiran dan sharing pengalaman sebagai langkah merumuskan berbagai alternatif perbaikan karya yang problematik tersebut. 
d. Fase keempat: mahasiswa berkontak argumen berkenaan dengan alternatif yang ditawarkan pada tahap sebelumnya.

e. Fase kelima: mahasiswa mulai bereksperimen untuk memperbaiki karya dengan jalan memilih berbagai argumen dan alternatif perbaikan karya seperti yang dibahas pada tahap sebelumnya.

f. Fase keenam: mahasiswa meninjau kembali karya yang ditulisnya berdasarkan masukan/pengalaman dibengkel. Pada tahap ini mahasiswa yang karyanya dibahas mempertimbangkan kembali perlu atau tidaknya melakukan perbaikan terhadap karyanya. (Abidin, 2005: 20)

Model ini menuntut mahasiswa pembelajarnya untuk memiliki kemampuan kreatif dan terbuka menerima pendapat orang lain serta memiliki semangat bekerja sama. Reaksi dari dosen terutama dibutuhkan pada fase kedua sampai fase keempat. Tugas dosen pada kedua fase ini adalah mengusahakan membangkitkan kemampuan respons kreatif mahasiswa sebagai alat proses berpikir. Dosen harus menerima semua respons mahasiswa agar mereka merasa diterima untuk lebih mengembangkan ekspresi kreatifnya.

Unsur penunjang yang secara optimal dapat berdampak pada pelaksanaan model ini adalah kelompok yang aktif dan kreatif dan karya mahasiswa yang sifatnya masih problematik. Penerapan model ini memberikan kesempatan kepada mahasiswa untuk mengembangkan kemampuan kreatif dalam menulis. Oleh sebab itu, dosen harus mencatat berbagai pandangan individu mahasiswa untuk mengatur dan mengikat pola berpikir mahasiswanya dan mencoba mempengaruhi pernyataan psikologis yang mungkin untuk menghasilkan respons kreatif mahasiswa. Sebagai tambahan, dosen juga harus memberikan dorongan kepada mahasiswa yang segan mengungkapkan perasaannya berkenaan dengan hal-hal yang tidak masuk akal, fantastik, simbolik, dan hal lain yang dibutuhkan untuk menjadi bahan pikiran yang sifatnya tiba-tiba. Dosen harus menyetujui semua respons siswa untuk meyakinkan mahasiswa bahwa tidak ada penilaian mutlak tentang ekspresi kreatifnya sehingga mahasiswa mampu membangun perspektif yang segar pada masalah yang dibahasnya.

Model bengkel sastra memberi dampak instruksionalnya dalam hal (1) peningkatan kreativitas dan kemampuan menulis, (2) pengembangan strategi merespons yang kreatif, dan (3) memecahkan masalah berkenaan dengan penulisan karya. Dampak penyertanya ialah dalam hal (1) pembentukan rasa percaya diri, (2) penciptaan keterbukaan menerima pendapat orang lain, (3) pembinaan kerja sama, dan (4) terciptanya berbagai model pembelajaran yang dapat diterapkan pada jenjang sekolah dasar.

\section{Konsep Menulis Puisi}

Menulis adalah proses kegiatan pikiran manusia yang hendak mengungkapkan kandungan jiwanya kepada orang lain atau kepada dirinya sendiri dalam bentuk tulisan. Menulis juga dapat dipandang sebagai kemampuan menuangkan ide dan gagasan ke dalam bentuk tulisan tertentu. Salah satu bentuk tulisan ini adalah puisi. 
Puisi merupakan karya sastra yang menekankan aspek kepadatan bahasa dan makna. Ini berarti puisi merupakan karya sastra yang menggunakan bahwa seefektif mungkin untuk mengungkapkan makna sebanyak mungkin. Oleh sebab itu, puisi dibangun atas unsur pembangun berupa tema, pilihan kata, pencitraan, kata imajinatif, rima, tipografi, nada, rasa, dan amanat.

Waluyo (1987: 25) memberikan definisi yang berbeda mengenai puisi. Menurut Waluyo puisi adalah bentuk karya sastra yang mengungkapkan pikiran dan perasaan secara imajinatif dan disusun dengan mengonsentrasikan semua kekuatan bahasa dengan pengonsentrasian struktur fisik dan struktur batin. Dengan demikian puisi adalah peluapan spontan dari perasaan-perasaan penuh daya yang bercikal bakal dari emosi yang berpadu kembali dalam kedamaian.

Bertemali dengan beberapa pendapat di atas, Abidin dan Astuti (2012: 3) menyatakan bahwa puisi sebagai salah satu genre karya sastra tentulah tidak bisa lepas dari bahasa sebagai media utamanya. Oleh karena itu, dalam pandangan sederhana mendefinisikan makna puisi haruslah terikat kuat dengan bahasa yang terkandung dalam sebuah puisi. Bahasa puisi tentu saja unik, estetis, sekaligus kaya makna. Bahasa puisi adalah bahasa yang unik sebab dipilih secara cermat oleh penulisnya guna mampu menggambarkan tujuan penulisan puisi tersebut, baik dalam hal pengimajian maupun dalam hal konkretisasi. Oleh sebab itu pulalah, ada yang mengatakan bahwa bahasa puisi berbeda dengan bahasa sehari-hari dan bahkan mungkin bertentangan dengan teori tata bahasa.

Dalam proses penulisan puisi, daya imajinatif memegang peranan penting. Daya imajinatif inilah yang mendorong kepekaan penulis timbul. Oleh sebab itu dalam prosesnya, menulis puisi harus diawali dengan pembinaan kemampuan imajinatif dan kepekaan terhadap lingkungan sebagai sumber penciptaan. Beberapa langkah yang harus ditempuh dalam proses menulis puisi antara lain dikemukakan Endraswara (2005) sebagai berikut.

1) Tentukan tema puisi sebagai hasil kontemplasi terhadap fenomena hidup dan kehidupan manusia.

2) Kembangkan tema tersebut dengan menggunakan pilihan kata yang baik.

3) Bangun suasana dalam puisi dengan menggunakan pencitraan.

4) Kembangkan makna puisi secara prismatis dengan menggunakan kata-kata yang mengandung daya imajinatif.

5) Susunlah puisi dengan memperhatikan aspek keindahan bahasa dan bunyi dengan memperhatikan aspek musikalitas puisi (rima).

6) Sajikan puisi dalam bentuk yang khas (tipografi yang unik).

Sumardjo (2004: 63-64) menyatakan bahwa untuk menilai sebuah karya sastra kita dapat membuat garis besar pedomannya. Pedoman ini bersifat umum, artinya kita menempatkan karya sastra itu sebagai suatu bentuk yang seharusnya menurut aturan konvensi yang telah ada. Tentu saja banyak karya sastra yang berusaha merombak konvensi yang telah ada, karena itu telah menjadi sifat abadi kesenian yang selalu berusaha mencari pembaharuan-pembaharuan di segala segi. Tetapi bagaimana juga sebuah pembaharuan tidak bisa melepaskan diri dari bentuk-bentuk yang seharusnya ada. Yang terpenting adalah suatu kesan apakah karya sastra itu 
berhasil membentuk kesatuan dalam dirinya. Mungkin saja ada suatu unsur yang dihilangkan, tetapi unsur itu akan terasa menyatu dengan unsur yang lain.

Bertemali dengan hal ini, Abidin (2012) menyatakan bahwa kriteria penulisan puisi dapat bertolak dari kemampuan dalam membangun harmoni atau keselarasan unsur-unsur puisi. Misalnya, penilaian dapat memperhatikan ketepatan dalam menyusun citraan, diksi, majas, rima ritma, dan tipografi. Harmonisasi unsur-unsur kemudian dapat dikaitkan dengan efek yang dimunculkannya. Mungkin saja unsurunsur itu sengaja dibuat menjadi tidak selaras. Akan tetapi, hal itu difungsikan agar sesuai dengan tema, nada, rasa, dan tujuan dari pengarangnya. Penilaian terakhir adalah inovasi kreatif. Di sini dapat dilihat apakah puisi yang dibuat merupakan hasil renungan yang mendalam setelah berkutat dari tradisi puisi yang ada atau bukan? Bila dilakukan, puisi dapat berupa reaksi atau inovasi kreatif dari tradisi yang digelutinya.

\section{Konsep Musikalisasi Puisi}

Musikalisasi puisi, seperti halnya deklamasi atau pembacaan puisi, rampak puisi, dan dramatisasi puisi adalah salah satu cara yang digunakan untuk menyampaikan dan mengekspresikan puisi kepada audiensi (Ari, 2008:7). Pada puisi yang disampaikan dengan cara musikalisasi, alat bantu utama ada pada musik (irama, nada, tempo, dan sebagainya). Musik diolah sedemikian rupa sebagai hasil dari penafsiran puisi yang dilakukan oleh pembuat musikalisasi puisi. Jenis penyampaian puisi dengan cara musikalisasi puisi ini ada banyak macamnya. Tetapi yang terpenting, musik yang dibuat adalah semata untuk kepentingan puisi, sehingga musik tersebut dapat menyampaikan pemahaman dan penghayatan tentang puisi itu kepada apresian.

Abdul Rani S, dkk (Ari, 2008:8) mendefinisikan "musikalisasi puisi sebagai upaya menampikan puisi dengan jalan memasukkan unsur-unsur musik secara dominan". Akan tetapi tujuan pemusikalisasian puisi bukanlah sekedar untuk menampilkan saja, di dalamnya ada upaya yang lebih dari itu, musik sengaja diciptakan sebagai sarana komunikasi dari pemusikalisasi dengan audiens. Mengacu pada hal di atas, dan juga pada keberagaman jenis musikalisasi yang berkembang, musikalisasi dapat didefinisikan sebagai sarana mengomunikasikan puisi kepada apresian melalui persembahan musik (nada, irama, lagu, atau nyanyian).

Dilihat dari cara penyajian suatu musikalisasi puisi, Ari (2008:9) menjelaskan musikalisasi puisi bisa dikelompokkan menjadi 3 jenis musikalisasi puisi, yaitu sebagai berikut.

a. Musikalisasi Puisi Awal

Yaitu, musikalisasi puisi yang dibawakan dengan cara pembacaan puisi yang dilatarbelakangi suatu komposisi musik, baik musik vokal maupun musik instrumental

b. Musikalisasi Puisi Terapan

Yaitu, musikalisasi puisi yang mana syair-syair puisi diterapkan menjadi lirik lagu, sebagaimana halnya lagu-lagu populer pada umumnya.

c. Musikalisasi puisi campuran 
Yaitu, musikalisasi puisi yang ditampilkan dengan cara menyuguhkan komposisi musik, yang di dalamnya ada sebuah puisi yang syair-syairnya ada yang dilagukan dan dinarasikan.

Langkah-langkah yang dapat dilakukan dalam musikalisasi puisi dijelaskan Ari, (2008:11-12) sebagai berikut.

a. Tahap persiapan

Pada tahap ini dipilih jenis puisi yang akan dijadikan materi ekspresi puisi.

b. Tahap pendahuluan

Pada tahap ini dilakukan kegiatan apresiasi dan memberi teks puisi yang akan diekspresikan.

c. Tahap pelaksanaan

Pada tahap ini dilakukan pemusikalisasian puisi dengan kerja bengkel sastra.

d. Tahap pementasan

Tahap ini dilakukan pementasan sebagai hasil kegiatan memusikalisasikan puisi.

\section{Metode Penelitian}

Model penelitian yang digunakan penulis adalah model penelitian mixed methods tipe explanatory. Bertemali dengan metode ini, ada dua model penelitian yang digabungkan dalam penelitian ini yakni penelitian kuantitatif dan kualitatif. Metode pertama yang penulis pilih untuk mewakili model penelitian kuantitatif ialah metode penelitian eksperimen berulang. Metode kedua yang penulis pilih mewakili penelitian kualitatif ialah metode studi kasus dengan desain multikasus holistik.

Populasi penelitian ini adalah mahasiswa PGSD semester III UPI Kampus Cibiru yang mengikuti mata kuliah Pembelajaran Bahasa dan Sastra Indonesia di Kelas Tinggi sebanyak 7 kelas. Pemilihan sampel dilakukan secara area random sampling. Berdasarkan pemilihan ini, sampel penelitian kelas eksperimen adalah mahasiswa semester III Kelas E yang mengontrak mata kuliah Pembelajaran Bahasa dan Sastra Indonesia di Kelas Tinggi dan sampel penelitian kelas kontrol adalah mahasiswa semester III Kelas F yang mengontrak mata kuliah Pembelajaran Bahasa dan Sastra Indonesia di Kelas Tinggi.

Data Penelitian dikumpulkan dengan menggunakan instrumen (1) wawancara, (2) observasi, (3) penilaian produk, (4) penilaian performa, (5) catatan lapangan, dan (6) dokumentasi. Data hasil penelitian diolah dengan menggunakan teknik pengolahan data kualitatif dan teknik pengolahan data kuantitatif dengan uji statistika dengan menggunakan uji perbedaan dua rerata yakni uji t.

\section{Hasil Penelitian dan Pembahasan}

\section{Hasil Penelitian}

Kemampuan menulis puisi antara mahasiswa di kelas eksperimen dan kelas kontrol pada saat pretes ternyata masih rendah. Kedua data ini dapat digambarkan sebagai berikut. 

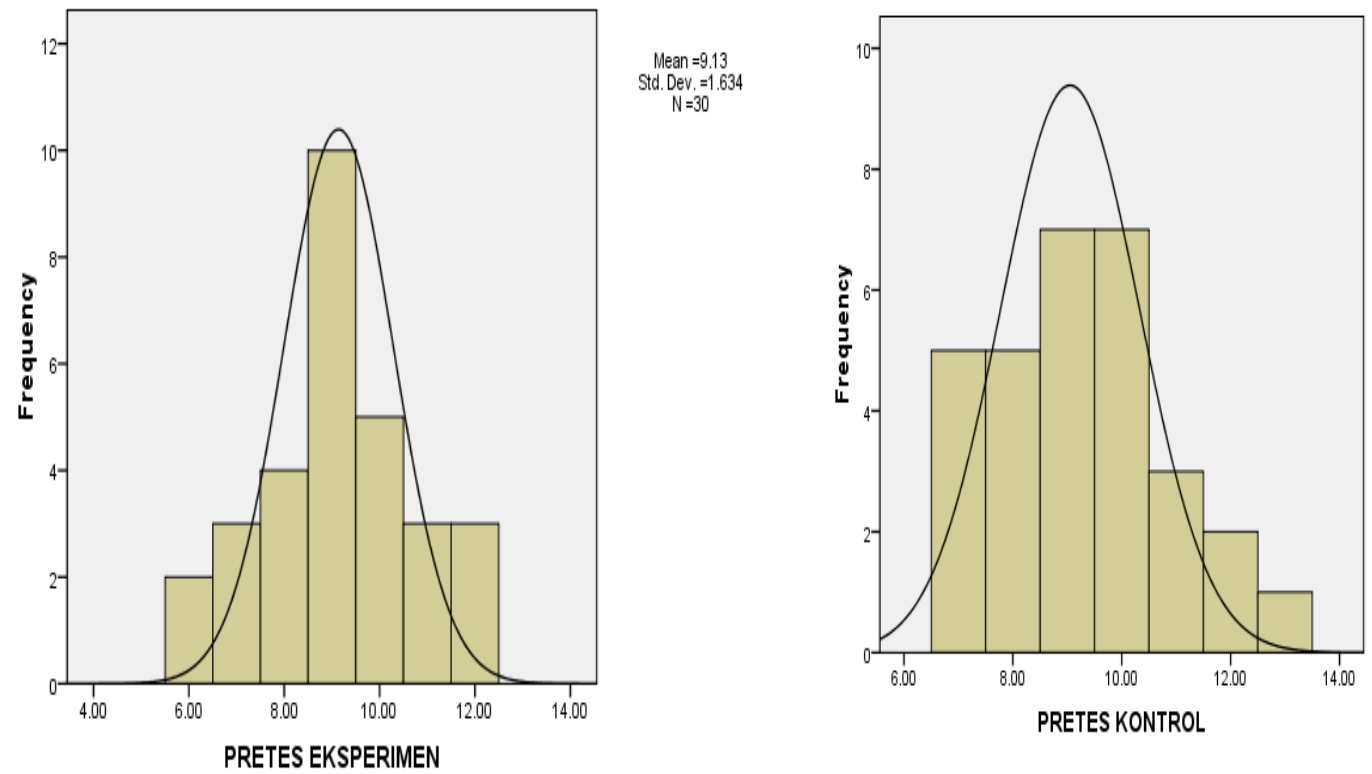

Mean $=9.27$
Std. Dev. $=1.617$
N $=30$

Gambar 2

Histogram Data Pretes Kemampuan Menulis Puisi Kelas Eksperimen dan Kelas Kontrol

Berdasarkan hasil analisis data dengan menggunakan uji $\mathrm{t}$ terhadap kedua data ini diketahui bahwa nilai $\mathrm{t}$ yang dihasilkan sebesar 0,318 dengan besar perbedaan dua rerata sebesar 0,133. Nilai Sig. (2-tailed) yang dihasilkan pada df sebesar 58 adalah 0,752. Ternyata Nilai Sig. (2-tailed) lebih besar dari taraf nyata yang diajukan sebesar 0,05 $(0,752>0,05)$. Dengan demikian, dapat dikatakan bahwa tidak terdapat perbedaan yang signifikan antara kemampuan menulis puisi mahasiswa kelas eksperimen dan kelas kontrol.

Ditinjau dari rata-rata yang diperoleh pada saat postes, kemampuan mahasiswa kelas eksperimen yakni mahasiswa PGSD UPI Kampus Cibiru yang mendapatkan pembelajaran dengan menggunakan model bengkel sastra dalam menulis puisi sudah mengalami peningkatan dibanding rata-rata skornya pada saat pretes. Skor hasil postesnya dapat dikategorikan cukup tinggi. Di sisi lain, rata-rata kemampuan mahasiswa kelas kontrol yang diperoleh pada saat postes juga sudah mengalami peningkatan dibanding rata-rata skornya pada saat pretes. Namun demikian, skor hasil postesnya hanya dikategorikan cukup. Data ini dapat disajikan dalam histogram sebagai berikut. 


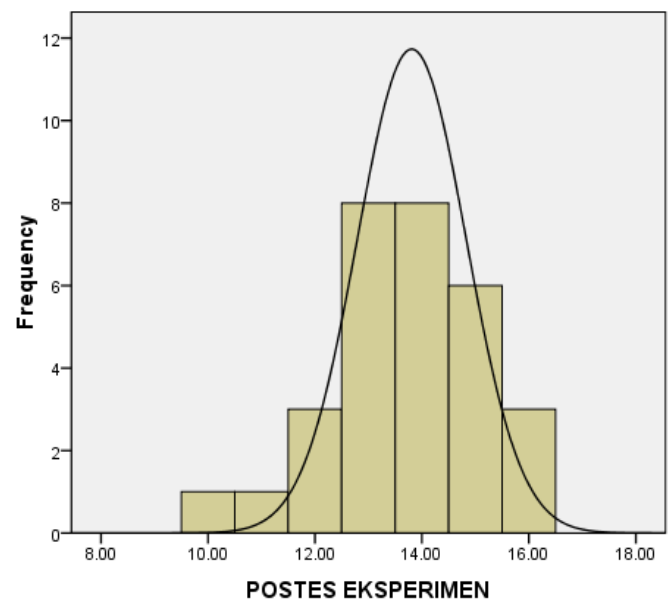

POSTES KONTROL

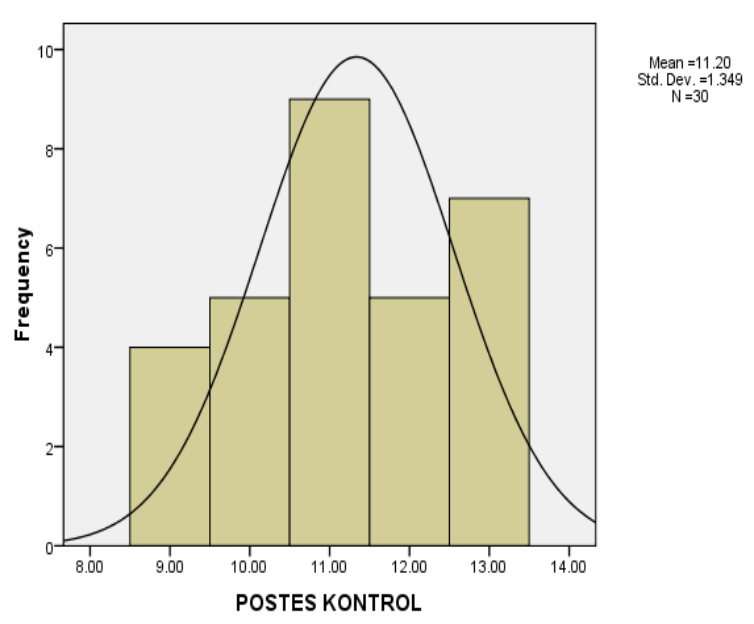

Mean $=11.20$
Std. Dev. $=1.349$
$N=30$

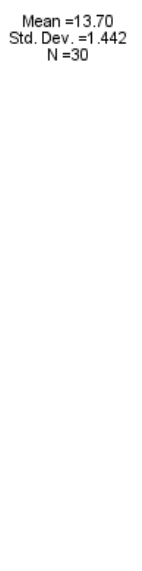

Gambar 3

Histogram Data Postes Kemampuan Menulis Puisi Kelas Eksperimen dan Kelas Kontrol

Berdasarkan hasil uji beda dua rerata dapat disimpulkan bahwa terdapat perbedaan yang signifikan antara kemampuan menulis puisi mahasiswa kelas eksperimen yang mendapatkan pembelajaran dengan model bengkel sastra dan kelas kontrol yang tidak mendapatkan pembelajaran dengan model bengkel sastra. Hal ini berarti penerapan model bengkel sastra berpengaruh dan berkontribusi positif bagi peningkatan kemampuan mahasiswa menulis puisi.

Kemampuan memusikalisasi puisi antara mahasiswa di kelas eksperimen dan kelas kontrol pada saat pretes ternyata masih rendah. Kedua data ini dapat digambarkan sebagai berikut.
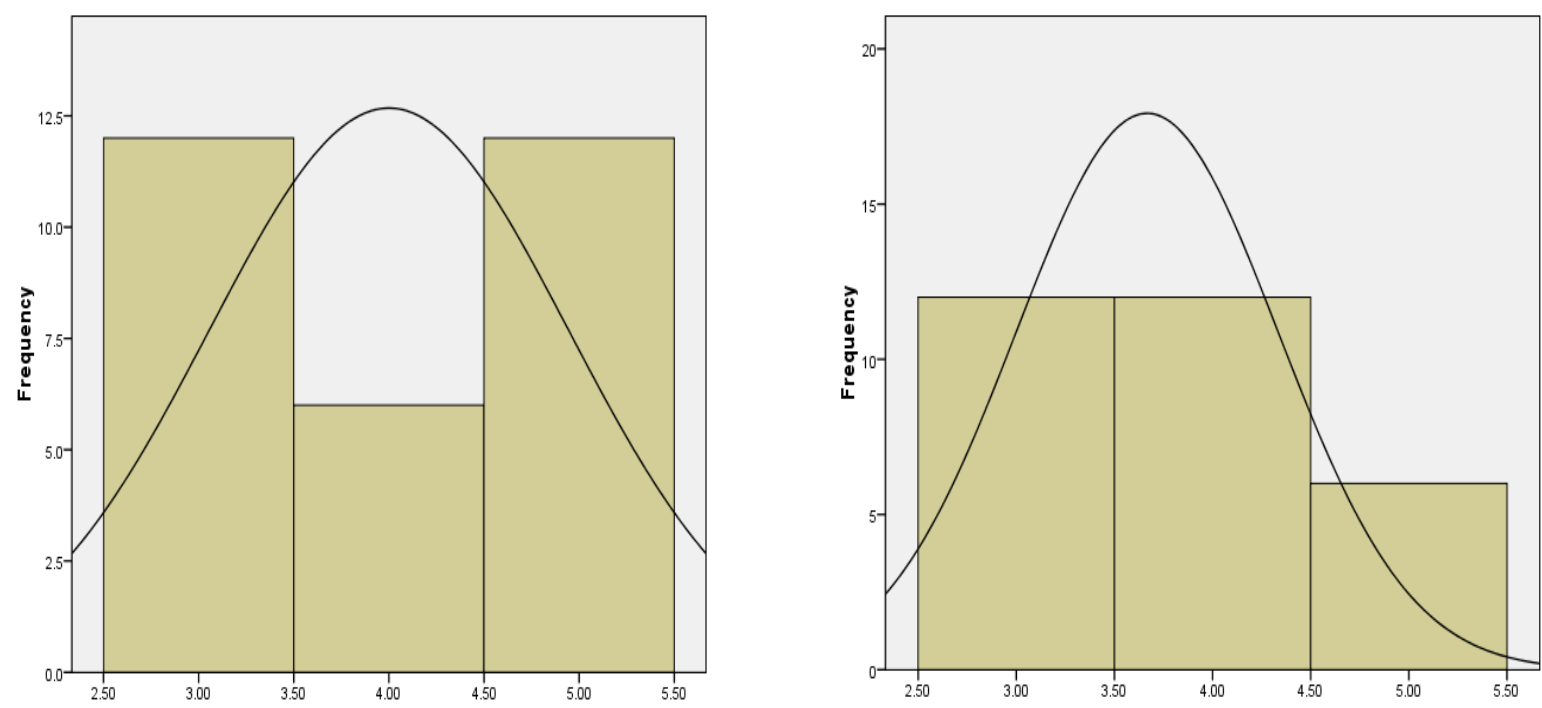

Gambar 4

Histogram Data Awal Kemampuan Memusikalisasi Puisi Kelas Eksperimen dan Kelas Kontrol 
Ditinjau dari rata-rata yang diperoleh pada saat eksperimen ke-2, kemampuan mahasiswa kelas eksperimen yang mendapatkan pembelajaran dengan menggunakan model bengkel sastra dalam memusikalisasi puisi sudah mengalami peningkatan dibanding rata-rata skornya pada saat perlakuan ke-1. Skornya dapat dikategorikan cukup tinggi. Di pihak lain, rata-rata yang diperoleh mahasiswa kelas kontrol yang tidak menggunakan model bengkel sastra dalam memusikalisasi puisi pada saat pembelajaran ke-2 juga mengalami peningkatan dibanding rata-rata skornya pada saat perlakuan ke-1. Namun demikian rata-rata skornya hanya dikategorikan cukup. Data ini dapat disajikan dalam histogram sebagai berikut.
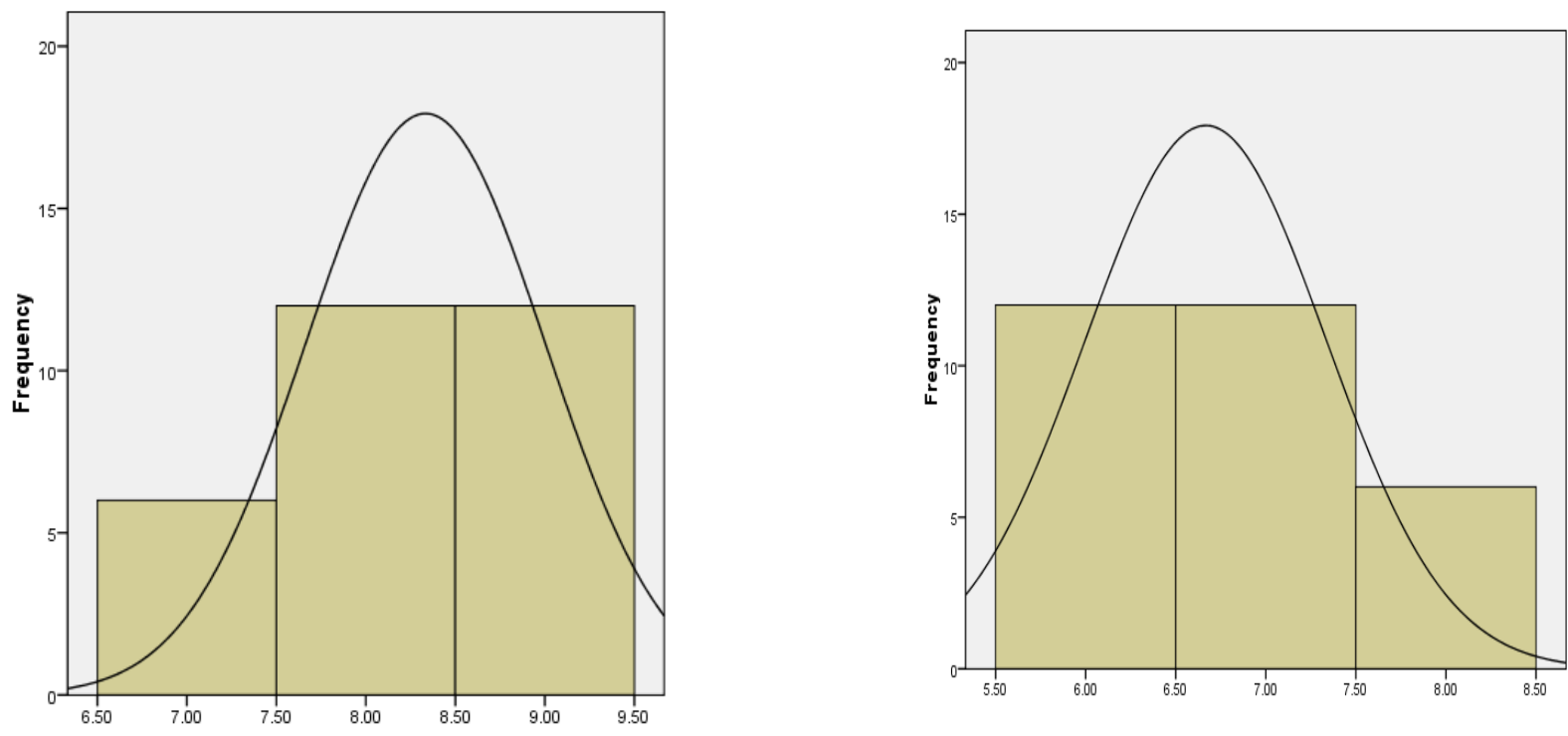

\section{Gambar 5}

Histogram Data Akhir Kemampuan Memusikalisasi Puisi Kelas Eksperimen dan Kelas Kontrol

Berdasarkan hasil uji beda dua rerata dapat disimpulkan bahwa terdapat perbedaan yang signifikan antara kemampuan memusikalisasi puisi mahasiswa kelas eksperimen yang mendapatkan pembelajaran dengan model bengkel sastra dan kelas kontrol yang tidak mendapatkan pembelajaran dengan model bengkel sastra. Hal ini berarti penerapan model bengkel sastra berpengaruh dan berkontribusi positif bagi peningkatan kemampuan mahasiswa memusikalisasi puisi.

Berdasarkan hasil wawancara dan observasi, diketahui bahwa faktor utama yang memengaruhi kemampuan mahasiswa menulis puisi dapat dikategorikan menjadi 3 kategori utama sebagai berikut.

a. Pemahaman unsur intrinsik puisi.

b. Kebiasaan menulis.

c. Latihan dan bimbingan penulisan.

Berdasarkan ketiga kategori utama di atas, dapat dikemukakan bahwa sebagian besar mahasiswa menyadari bahwa menulis puisi bukanlah hal yang 
mudah untuk dilakukan. Guna mampu menulis yang baik, mereka harus memahami konsep puisi sehingga mampu menulis sesuai konvensi genre yang diharuskan. Kebiasaan dan latihan menulis di sisi lain disadari merupakan dua hal mutlak yang harus dilakukan agar mampu menulis dengan baik. Kedua hal ini dipandang sebagai kunci ganda yang mampu membina kemampuan sekaligus motivasi menulis.

Berdasarkan hasil wawancara dan observasi, diketahui bahwa faktor utama yang memengaruhi kemampuan mahasiswa memusikalisasi puisi dapat dikategorikan menjadi 3 kategori utama sebagai berikut.

a. Keterampilan memainkan alat musik.

b. Kebiasaan berekspresi.

c. Latihan dan bimbingan musikalisasi.

Berdasarkan ketiga kategori utama di atas, dapat dikemukakan bahwa sebagian besar mahasiswa menyadari bahwa memusikalisasi puisi bukanlah hal yang mudah untuk dilakukan. Guna mampu memusikalisasi puisi dengan baik, mereka harus mampu menggunakan beragam alat musik sehingga mereka akan mampu mengaransemen puisi menjadi lagu yang indah. Kebiasaan dan latihan menulis di sisi lain disadari merupakan dua hal mutlak yang harus dilakukan agar mampu membina daya intuitif dan daya kreatif memusikalisasi. Melalui pembiasaan dan bimbingan kemampuan mereka terasah sehingga mampu menghasilkan kreasi musikalisasi yang lebih baik.

\section{Pembahasan}

Penelitian yang dilaksanakan penulis membuahkan hasil yang sangat baik. Kemampuan mahasiswa menulis puisi antara kelas eksperimen dan kelas kontrol pada saat pretes dapat dikatakan tidak memiliki perbedaan yang signifikan. Namun pada saat postes perbedaan kemampuan dua kelas ini mengalami perbedaan yang sangat signifikan. Hal ini berarti model bengkel sastra yang dioptimalisasi telah mampu meningkatkan kemampuan mahasiswa dalam menulis puisi. Hal ini dibuktikan dengan hasil pengolahan data dengan menggunakan uji $t$ yang menunjukkan bahwa thitung yang dihasilkan ternyata bernilai signifikan.

Peningkatan kemampuan ini meliputi seluruh aspek puisi yaitu tema, diksi, pencitraan, pengimajian, rima, tipografi, amanat, nada dan rasa. Namun demikian jika dianalisis secara lebih mendalam aspek yang paling meningkat adalah aspek diksi dan pengimajian dan yang peningkatannya paling kecil adalah aspek tema dan amanat. Dengan demikian, tujuan instruksional dari penerapan model bengkel sastra dalam penelitian ini dapat tercapai.

Sejalan dengan keberhasilan dalam meningkatkan kemampuan menulis puisi, kemampuan memusikalisasi puisi para mahasiswa pun meningkat. Kemampuan mahasiswa memusikalisasi puisi antara kelas eksperimen dan kelas kontrol pada saat pretes dapat dikatakan tidak memiliki perbedaan yang signifikan. Namun pada saat postes perbedaan kemampuan dua kelas ini mengalami perbedaan yang sangat signifikan. Hal ini berarti model bengkel sastra yang dioptimalisasi telah mampu meningkatkan kemampuan mahasiswa dalam memusikalisasi puisi. Hal ini dibuktikan dengan hasil pengolahan data dengan menggunakan uji $t$ yang menunjukkan bahwa thitung yang dihasilkan ternyata bernilai signifikan. 
Peningkatan kemampuan memusikalisasi puisi meliputi seluruh aspek musikalisasi puisi yaitu aransemen, penghayatan dan penampilan. Namun demikian jika dianalisis secara lebih mendalam aspek yang paling meningkat adalah aspek penghayatan dan aransemen dan yang peningkatannya paling kecil adalah performa. Dengan demikian, tujuan instruksional dari penerapan model bengkel sastra dalam penelitian ini dapat tercapai.

Keberhasilan penggunaan model bengkel sastra dalam meningkatkan kemampuan mahasiswa menulis dan memusikalisasi puisi menunjukkan bahwa model tersebut dapat digunakan dalam proses perkuliahan di perguruan tinggi. Model bengkel sastra merupakan model pembelajaran yang memegang peranan penting dalam proses belajar mahasiswa. Dengan adanya model bengkel sastra dalam proses pembelajaran sastra, mahasiswa dapat memiliki pengalaman mengapresiasi sastra dengan jalan menganalisis atau mengkritisi kelemahan dan keunggulan karya sastranya sendiri serta orang lain, sehingga mahasiswa dapat belajar secara efektif dan efisien.

Model bengkel mampu mengembangkan kemampuan apresiasi sastra dengan pendekatan readers respons. Melalui model ini mahasiswa terbiasa memberikan respons terhadap karya sastra. Lebih jauh mereka akan berargumentasi sehingga mereka akan berusaha mempertahankan kebenaran respons yang diberikannya. Respons yang mereka berikan harus pula mampu memperbaiki sebuah karya sastra. Dengan demikian kemampuan menulis dan memusikalisasi puisi benar-benar terasah dengan menggunakan model bengkel sastra ini.

Jika dibandingkan dengan penelitian-penelitian terdahulu, dapat dikatakan bahwa penelitian ini sejalan dengan penelitian yang dilakukan Abidin (2005), Rohayati dan Abidin (2009) serta penelitian Putra (2012). Kenyataan ini semakin memperkuat bahwa model bengkel sastra dapat digunakan untuk seluruh aspek pembelajaran sastra. Jika dikaitkan dengan penelitian proses lainnya, penelitian yang dilakukan Sayuti, et al. (2009) pun selaras dengan penelitian ini. Hal ini berarti bahwa pembelajaran berbasis aktivitas merupakan kunci keberhasilan pengembangan kemampuan siswa bersastra.

Berdasarkan uraian di atas, penerapan model bengkel sastra guna meningkatkan kemampuan mahasiswa dalam menulis puisi dan memusikalisasi puisi dapat dikatakan berhasil. Keberhasilan penerapan model bengkel sastra terutama dalam meningkatkan kemampuan peserta bengkel dalam mengembangkan diksi, pengimajian, pencitraan, dan ketetapan menentukan penggunaan rima. Dalam hal musikalisasi, kemampuan penampilan perlu mendapatkan perhatian lebih lanjut.

\section{E. Kesimpulan}

Berdasarkan hasil analisis data, penelitian ini menyimpulkan beberapa hal sebagai berikut.

1. Terdapat perbedaan yang signifikan antara kemampuan menulis puisi mahasiswa kelas eksperimen yang mendapatkan pembelajaran dengan model bengkel sastra dan kelas kontrol yang tidak mendapatkan pembelajaran dengan model bengkel sastra. Hal ini berarti penerapan model bengkel sastra 
berpengaruh dan berkontribusi positif bagi peningkatan kemampuan mahasiswa menulis puisi.

2. Terdapat perbedaan yang signifikan antara kemampuan memusikalisasi puisi mahasiswa kelas eksperimen yang mendapatkan pembelajaran dengan model bengkel sastra dan kelas kontrol yang tidak mendapatkan pembelajaran dengan model bengkel sastra. Hal ini berarti penerapan model bengkel sastra berpengaruh dan berkontribusi positif bagi peningkatan kemampuan mahasiswa memusikalisasi puisi.

3. Faktor utama yang memengaruhi kemampuan mahasiswa menulis puisi dapat dikategorikan menjadi 3 kategori utama yakni (1) pemahaman unsur intrinsik puisi, (2) kebiasaan menulis, dan (3) latihan dan bimbingan penulisan. Faktor utama yang memengaruhi kemampuan mahasiswa memusikalisasi puisi dapat dikategorikan menjadi 3 kategori utama yakni (1) keterampilan memainkan alat musik; (2) kebiasaan berekspresi, dan (3) latihan dan bimbingan musikalisasi.

\section{DAFTAR PUSTAKA}

Abidin, Y. (2012) Pembelajaran Bahasa Berbasis Pendidikan Karakter: Bandung: Refika Aditama.

Abidin, Y. 2005 Penerapan Model Bengkel Sastra sebagai Upaya Meningkatkan Kemampuan Mahasiswa dalam Menulis Cerita Pendek dan Menyusun Strategi Pembelajaran Menulis Cerita Pendek. Tesis. Bandung: UPI (Tidak Dipublikasikan)

Abidin, Y. dan Astuti. S. (2012) Puisi dalam Multiperspektif. Bandung: HSAA Press.

Ari, Kpin. (2008). Musikalisasi Puisi. Yogyakarta: Hikayat Publishing.

Endraswara, S. (2005). Metode E Teori Pengajaran Sastra. Yogyakarta: Buana Pustaka.

Putra, A.W. (2012) Pembelajaran Pemeranan pada Mata Kuliah Apresiasi Drama dengan Menggunakan Model Bengkel Sastra Sebagai Upaya Mengembangkan Karakter Mahasiswa. Tesis. Bandung: UPI (Tidak Dipublikasikan)

Rohayati, E. dan Abidin, Y. (2009) Penerapan Model Bengkel Sastra untuk Meningkatkan Kemampuan Mahasiswa Menulis dan Mengapresiasi Sastra. Laporan Penelitian. Bandung: LPPM UPI. (Tidak Dipublikasikan)

Sayuti (2009) Model Pembinaan Penulisan Karya Sastra Kolaboratif-Produktif untuk Guru dan Siswa SMA di Daerah Istimewa Yogyakarta. Laporan Stranas. Yogyakarya: UNY.

Sumardjo, Y. (2004). Seluk Beluk dan Petunjuk Menulis Cerita Pendek. Bandung: Pustaka Latifah.

Waluyo, H. J. (1987) Teori dan Apresiasi Puisi. Jakarta: Erlangga. 